\title{
Long-Term Outcomes of Bronchiectasis Surgery: 108 Cases
}

\section{Bronşektazi Cerrahisinin Uzun Dönem Sonuçları; 108 Olgu}

\author{
Erkan AKAR ${ }^{1}$ Miktat Arif HABERAL ${ }^{1}$
}

\section{$\underline{0 ̈ Z}$}

Amaç: Cerrahi rezeksiyon uygulayıp uzun süre takip ettiğimiz olguların sonuçlarını değerlendirmeyi amaçladık.

Araçlar ve Yöntem: 2005 ile 2019 tarihler arasında kliniğimize başvuran, bronşektazi tanısı alan ve opere edilen 108 hastanın dosyaları (38 erkek, 70 kadın; ortalama yaş 23.03 yıl (18-63)) geriye dönük olarak değerlendirildi. Ameliyat sonrası hastaların takipleri; akciğer grafisi, SFT, tam kan, CRP takibi ve ameliyat öncesi şikâyetleri (öksürük, balgam çıkarma, tekrarlayan akciğer enfeksiyonları) sorgulanıp kaydedildi. Hastaları ameliyat sonrası değerlendirirken, ameliyat öncesi şikâyetlerin olmaması, şikâyetlerin azalması ve değişiklik olmaması şeklinde kategorize edildi.

Bulgular: Yüz sekiz hastaya 115 cerrahi işlem yapıldı. Cerrahi sonrası en fazla görülen komplikasyon atelektazi ve uzamış hava kaçağı idi. Cerrahi olarak çoğunlukla lobektomi uygulandı. Postoperatif morbidite 44 hasta ile \%41 idi. Mortalite ise 5 hasta ile \%5 idi. Tam düzelme 87 hasta (\%81), 15 hasta da (\%14) ise şikâyetleri kabul edilebilir düzeyde ve antibiyotik kullanma gereksinimi vardı. Altı hastada $(\% 5)$ ise başka lobda nüks etti. Hastalarımızın ortalama takip süresi 3.71 yıl (8 ay-12 yıl) idi.

Sonuç: Uygun olarak tedavi edilmeyen bronşektazi hastaları enfeksiyonların kısır döngüsü ile seyreder. Cerrahi tedaviyi gerektiren risk faktörleri morbiditeyi de belirler. Etkilenen dokuların cerrahi rezeksiyonu ile bu kısır döngü sonlandırılabilir.

Anahtar Kelimeler: bronşektazi; komplikasyon; postoperative; rezeksiyon

\section{ABSTRACT}

Purpose: We aimed to analyze the cases that we monitored for long term after applying surgical resection.

Materials and Methods: Admitted to our clinic between 2005 and 2019, the files of 108 patients (38 male, 70 female, mean age of 23.03 years (18-63)), who visited our clinic, were diagnosed with bronchiectasis and operated on, were retrospectively analyzed. For the monitoring of the patients after surgery, chest radiography, PFT, CBC and CRP follow-up results, and their preoperative complaints (coughing, expectoration, recurrent pulmonary infections) were examined and recorded. While assessing the patients' status after the surgery, they were categorized as disappearance of the preoperative complaints, decrease in the complaints, and no change in the complaints.

Results: 115 surgical operations were carried out on 108 patients. The most frequently encountered complications after surgery were atelectasis and prolonged air leak. Mostly lobectomy was applied as surgery. Postoperative morbidity was seen in 44 patients (41\%). Mortality was seen in 5 patients (5\%). Complete recovery was observed in 87 patients (81\%), while the complaints of 15 patients (14\%) were on an acceptable level, and they needed to use antibiotics. The disease relapsed in another lobe in 6 patients $(5 \%)$. The mean time of monitoring among our patients was 3.71 years ( 8 months -12 years).

Conclusion: Infections fall into a vicious circle in bronchiectasis patients who are not appropriately treated. The risk factors that require surgery determine morbidity. This cycle may be ended by the surgical resection of the affected tissues.

Keywords: bronchiectasis; complication; postoperative; resection

Received: 17.11.2020; Accepted: 24.04.2021

${ }^{1}$ Health Sciences University, Bursa Yuksek Ihtisas Training and Research Hospital, Department of Thoracic Surgery, Bursa, Turkey

Corresponding Author: Assoc. Prof. Erkan Akar, Department of Thoracic Surgery, Health Sciences University, Bursa Yuksek Ihtisas Training and Research Hospital, Bursa, Turkey. e-mail: drerkanakar@hotmail.com

How to cite: Akar E, Haberal MA. Long-term outcomes of bronchiectasis surgery: 108 cases. Ahi Evran Med J. 2021;5(2):140-145. DOI: 10.46332/aemj.827315 


\section{INTRODUCTION}

Bronchiectasis is a permanent enlargement of airways caused by chronic bronchial inflammation that develops based on insufficient elimination of various microorganisms in respiratory pathways and recurrent infections. ${ }^{1}$ Medical treatment (antibiotics, postural drainage, bronchodilator treatment) is sufficient for most of the cases. Surgical treatment is preferred only in cases that have unique symptoms such as hemoptysis, which is resistant to treatment or on which treatment is insufficient, or recurring episodes of pneumonia. ${ }^{2,3}$ Different publications reported the rates of mortality in surgical treatment to be in the range of $0-3.4 \% .4$ There is little information on long-term outcomes after surgery. ${ }^{5}$

The purpose of this study is to share our long-term results on the clinical and surgical characteristics regarding bronchiectasis patients who received surgical treatment.

\section{MATERIAL and METHODS}

The medical records of 108 patients (38 male, 70 female, mean age of 23.03 years (Min-Max: 18-63)), who visited our Thoracic Surgery Clinic between January 2005 and February 2019, were diagnosed with bronchiectasis and received surgical resection, were retrospectively analyzed. The patients were directed to our clinic from the emergency services and the pulmonology clinic. Medical histories, physical examination and hematological and biochemical examination results were recorded for all the patients. The respiratory reserves of the patients were determined by respiratory function tests and pulmonary perfusion scintigraphy in cases with limited lung functions. No additional respiratory examination was carried out for the patients with forced expiratory volume-one second (FEV1) values of 2 liters (L) or above or FEV1 values of $80 \%$ of the expected value and no exertional dyspnea (accepted to be suitable for all types of resection including pneumonectomy). FEV1 values of $1.5 \mathrm{~L}$ or above and no exertional dyspnea were accepted to be sufficient for lobectomy. In patients who did not meet the criteria above, estimated postoperative FEV1 values of $40 \%$ or above were accepted to be sufficient for lobectomy. Thorax computerized tomography (CT) and high-resolution computerized tomography (HRCT) were used in the radiological examination of the patients. Additionally, 12 patients received pulmonary perfusion scintigraphy, five patients received esophageal swallow test, and nine patients received CT angiography as additional tests. Microbiological tests were run on the phlegm samples of all patients. In patients with purulent expectoration or those with reproduction in their phlegm cultures were treated for 10 days with antibiotics treatment, mucolytic agents, bronchodilator, anti-inflammatory and postural drainage. Their surgical indications included having experienced lung infections that required usage of antibiotics at least five times a year despite medical/conservative treatment, chronic coughing and expectoration that do not respond to medical treatment, hemoptysis and destroyed lobe. Sufficient pulmonary and cardiac reserves and regional involvement were our criteria for suitability of surgery.

For the long-term outcomes, the patients were reached by mail, telephone, or polyclinic examinations. The patients who could be reached were informed about the study, and ethics board approval was obtained. All patients were examined in terms of age, sex, symptoms, duration of symptoms, history of smoking, diagnosis methods, location of disease, type of surgery, duration of hospitalization, morbidity, mortality and long-term outcomes. Patient satisfaction was the main criterion for assessing the longterm outcomes. While assessing the patients' status after the surgery, they were categorized as disappearance of the preoperative complaints, decrease in the complaints and no change in the complaints. Complete patient satisfaction (complete disappearance of complaints) was accepted as complete recovery, reduction in complaints was accepted as partial recovery, and continuation of complaints without change was accepted as failure. Bursa Yuksek Ihtisas Training and Research Hospital clinical research ethics committee approval was obtained. (Decision number; 2011KAEK-25 2019/01-22 Date; 02.01.2019). 


\section{Method of Surgery}

A double-lumen endotracheal intubation tube (28 F doublelumen tube) was used under general anesthesia in each patient, and posterolateral thoracotomy was applied. Excessive dissection of the bronchia was avoided, and the bronchial stumps were supported by a living tissue (intercostal muscle flap or parietal pleura flap) or autologous fibrin (fibrin material derived from the patient's own blood). If they arose in the first 30 days after the surgery, adverse events were considered to be postoperative complications or mortality. The diagnoses of the patients were pathologically confirmed.

\section{RESULTS}

The male/female ratio was approximately $1 / 2$. There was a history of smoking in 43 patients. The mean duration of symptoms was 7.4 years (17 days - 62 months). Coughing and expectoration were the most frequently encountered complaints. There were comorbidities of other diseases in a total of 40 patients (46\%). 17 patients were people whose complaints started in their adulthood, and no etiological factors could be detected in this group. Eight of these patients received antituberculotic treatment in the past, and their current tuberculosis bacillus status was negative in their phlegm. Five of the patients with history of tuberculosis were of adult age. Three cases experienced tuberculosis in childhood (Table 1).

There was lest lung involvement in 55 patients (51\%) and right lung involvement in 53 patients $(49 \%)$. There was multiple lobe involvement in 32 patients (30\%), while there was single lobe involvement in 76 patients $(70 \%)$. The area where bronchiectasis was seen the most frequently was the lower-left lobe with 36 patients (33\%) (Table 2).

Complete resection (without leaving any bronchiectasis lung tissue behind) was applied on 102 patients (94\%), and partial resection was applied on 6 patients $(6 \%)$. In the patients with partial resection, complete resection could not be applied due to multisegmental involvement. In these patients, the decision for surgery was made due to frequently recurrent lung infection, complaints of nonresponsive coughing and expectoration, and recurrent hemoptysis (Table 3).

Table 1. General clinical characteristics of patients

\begin{tabular}{lcc}
\hline Variables & $\begin{array}{c}\text { Number of } \\
\text { Patients }\end{array}$ & $\%$ \\
\hline Sex & 70 & 65 \\
Female & 38 & 35 \\
Male & 43 & 40 \\
History of smoking & & \\
Prominent symptoms & 60 & 56 \\
Coughing and expectoration & 17 & 16 \\
Frequent lung infection & 10 & 9 \\
Hemoptysis & 8 & 7 \\
Febrility & 13 & 12 \\
Respiratory distress & & \\
Accompanying conditions & 14 & 13 \\
COPD & 8 & 7 \\
Tbc & 5 & 5 \\
Pneumonia & 7 & 6 \\
Diabetes & 10 & 9 \\
Hypertension & 4 & 4 \\
CHD & 2 & 2 \\
GER & & \\
\hline COPD: Chronic Obstructive Pulmonary Disease, Tbc: Tuberculosis, CHD: \\
Goronary Artery Disease & & \\
GER: Gastro-esophageal reflux. & & \\
\hline
\end{tabular}

Table 2. Resections

\begin{tabular}{lcc}
\hline Type of Resection & Number of Patients & $\%$ \\
\hline Lower left lobectomy & 36 & 35 \\
Upper right lobectomy & 10 & 10 \\
Lower right lobectomy & 18 & 17 \\
$\begin{array}{l}\text { Upper left lobectomy } \\
\text { Lower right bilobectomy }\end{array}$ & 2 & 2 \\
$\begin{array}{l}\text { Upper right lobectomy + } \\
\text { middle lobe }\end{array}$ & 12 & 12 \\
$\begin{array}{l}\text { medial segmentectomy } \\
\text { Middle right lobectomy }\end{array}$ & 4 & 4 \\
$\begin{array}{l}\text { Lower left lobectomy }+ \\
\text { lingulectomy }\end{array}$ & 9 & 9 \\
$\begin{array}{l}\text { Lower left lobectomy }+ \text { wedge } \\
\text { resection from the lingula }\end{array}$ & 15 & 1 \\
$\begin{array}{l}\text { Lower left lobectomy+ } \\
\text { decortication }\end{array}$ & 1 & 1 \\
\begin{tabular}{l} 
Total \\
\hline
\end{tabular} & 108 & 1 \\
\hline
\end{tabular}


Table 3. Postoperative complications

\begin{tabular}{lll}
\hline Complications & $\begin{array}{l}\text { Number of } \\
\text { Patients }\end{array}$ & $\%$ \\
\hline Atelectasis & 20 & 18.55 \\
Prolonged air leak & 10 & 9.25 \\
Empyema & 4 & 3.70 \\
Supraventricular arrhythmia & 3 & 2.77 \\
Pneumonia & 2 & 1.85 \\
Postoperative hemorrhage & 2 & 1.85 \\
Wound side infection & 1 & 0.92 \\
Bronchopleural fistula & 2 & 1.85 \\
Total & 44 & 40.74 \\
\hline
\end{tabular}

Mortality was observed in 5 patients (5\%). Eight complications occurred in a total of 44 patients (41\%). Hospital atelectasis $(n=20)$ and prolonged air leak $(n=10)$ were the most frequently encountered postoperative complications. There was empyema in 4 patients, pneumonia in 2 patients, bronchopleural fistula in 2 patients, postoperative hemorrhage in 2 patients and wound site infection in 1 patient. The mean duration of hospitalization was 13.4 (5-36) days. The mean time of monitoring was 3.71 years ( 8 months - 12 years). In terms of the long-term outcomes in general, there was complete recovery in 87 patients $(81 \%)$, partial recovery in 15 patients $(14 \%)$ and relapse in another lobe in 6 patients $(5 \%)$.

\section{DISCUSSION}

Improvements in the treatment of lung infections in children have reduced the incidence of bronchiectasis, thus decreasing the need for treatment. However, this condition still continues to be a health problem in developing countries. ${ }^{6}$ The most prevalent reason for bronchiectasis in developing countries is the insufficient treatment of pulmonary infections. On the other hand, other reasons such as pulmonary tuberculosis and untreated foreign bodies should be kept in mind. ${ }^{7,8}$ A study with 277 patients (children and adults) reported that the most prevalent reason for bronchiectasis $(77.6 \%)$ was insufficient treatment of lung infections. ${ }^{9}$ The most frequent patient complaint is phlegmy coughing, which deteriorates the quality of life of the patient and causes depression. ${ }^{10}$ Likewise, in our study, coughing and expectoration were the most frequent surgical indications, while infection was the top etiological factor. We also believe that hereditary factors may play a role in patients with accompanying pathologies in addition to bronchiectasis.

Before the widespread use of CT, the most frequently used methods to diagnose bronchiectasis were radiography and bronchography. ${ }^{11}$ Nevertheless, the advanced CT imaging techniques today allow surgeons to make better surgical plans by providing them with quality anatomic details, and bronchography is usually not needed. ${ }^{11,12}$ In our study, CT and HRCT provided the required data for all patients, and there was no need for bronchography in any patient. A study which compared HRCT and spiral CT reported that CT had $91 \%$ sensitivity and $99 \%$ specificity. The same authors stated that HRCT has higher sensitivity in suspected cases of bronchiectasis, and it is the imaging method that needs to be preferred due to lower doses of radiation. ${ }^{13}$ While magnetic resonance imaging has the advantage of being a radiationfree imaging method in the diagnosis and monitoring of bronchiectasis, HRCT is the gold standard method in confirming the diagnosis. ${ }^{14}$

Despite the clinical advancements in pulmonary surgery, the optimal treatment for bronchiectasis is still under debate. , $^{2,15}$ When medical treatment is insufficient, bronchiectasis patients are directed by pulmonology clinics to a pulmonary surgery clinic with an expectation of improvement in the symptoms. ${ }^{16}$ Most of our patients consisted of those who visited the emergency services with constant or recurrent complaints, those who were being monitored as inpatients by pulmonology clinics, or those who were directed to surgery with the expectation of partial or complete recovery in their symptoms.

The objective in bronchiectasis surgery is to increase quality of life and protect the patient from serious complications such as pulmonary abscess, empyema and hemoptysis. Moreover, in bronchiectasis, which is a progressive disease, 
it is needed to protect the healthy parenchyma by resecting the parenchymal segments that have been affected when the disease was local. ${ }^{2,7,15-17}$ In bronchiectasis, it is needed to perform complete anatomical resections that protect lung functions as much as possible. All types of resections are possible for this purpose. For sufficient lung functions, at least two lobes or six segments must be preserved. . $^{511,18,19}$ Noncolumnar disease, pseudomonas disease proven with phlegm culture and nonlocalized disease constitute the relative contraindications for the surgical treatment of bronchiectasis. ${ }^{14}$ Surgery is debatable in multisegmental and bilateral involvement. However, in cases where medical treatment is insufficient or situations such as hemoptysis that threaten life, palliative surgery should be considered. ${ }^{3}$ Bilateral bronchiectasis is not a contraindication for surgery. This is because even partial resection may provide considerable benefits to patients. Most of such patients to not need a second surgery after the first surgery. ${ }^{17}$

The rates of partial resection in the literature vary in the range of $5.8-35 \% .^{7,15,17,18,20}$ In their study, Kutlay et al. ${ }^{7}$ applied $89 \%$ partial resection on the patients and achieved perfect outcomes (complete disappearance of symptoms) $84 \%$, good outcomes (improvements in symptoms) by $14 \%$, and unsuccessful outcomes (no recovery in the symptoms) by $2 \%$. In the same study's group with $11 \%$ partial resection, while no patients became asymptomatic, the ratio of the patients with improved symptoms was $76 \%$ and the ratio of those with no improvement at all was $23.5 \%$. In another study with a patient group that received $89 \%$ partial resection, $74 \%$ of the patients became asymptomatic, $25 \%$ experience clinical improvement, and there was clinical failure in $1 \%$. The same study applied $11 \%$ partial resection on another group of patients, and the ratios of the asymptomatic patients, patients with improved symptoms and patients with no improvement were respectively reported as 9\%, 64\% and $27 \% .{ }^{17}$ Similarly, Ötgün et al. ${ }^{15}$ applied $24 \%$ partial resection. In their study, in the partial resection group, the symptoms completely disappeared by $15 \%$, there were improvements in the symptoms by $61 \%$, and the symptoms stayed the same by $23 \%$. In our study, there was complete recovery in 87 patients $(81 \%)$, partial recovery in 15 patients (14\%) and failure in 6 patients $(5 \%)$. The fact that the number of the asymptomatic patients in the partial resection group in our study was low may explained that there was no statistically significant difference between the asymptomatic group with complete resection and the asymptomatic group with partial resection despite the large difference.

Excessive dissection was avoided in all of our patients to prevent development of bronchial fistula after surgery, and the bronchial stumps were supported by a living tissue or autologous fibrin. Nevertheless, bronchial fistula developed in two cases. Similar studies did not provide information about the outcomes of supporting bronchial stumps. A study with 119 patients supported bronchial stumps with living tissues, and an issue of fistula was observed in one case. ${ }^{17}$ The study by Sirmal1 et al. ${ }^{11}$ with 176 cases used living tissue support, and no fistula occurred. Kutlay et al. ${ }^{7}$ study did not use a support, and fistula developed in one patient. Yüncü et al. ${ }^{16}$ did not use bronchial support and observed no fistula development.

The rates of mortality and morbidity were reported by Nadir et al. ${ }^{21}$ as $8 \%$ and $16 \%$, respectively, while Gürsoy et al. ${ }^{22}$ reported these as $1 \%$ and $16 \%$, respectively. In our study, these ratios were found as $5 \%$ and $41 \%$. A recent metaanalysis study concluded that the increased presence of comorbid diseases, such as heart disease and diabetes, in adult patients has increased surgical mortality. ${ }^{23}$ There was diabetes in 7 , hypertension in 10 , and coronary artery disease in 4 of our patients. Among the 5 cases with mortality, there were heart disease in 3 , and diabetes in 2 .

Consequently, the surgical treatment of bronchiectasis provides satisfactory long-term outcomes with acceptable mortality and morbidity rates. While the long-term outcomes of complete resection are much better, we believe that partial resection will also provide well-selected patients with significant benefits.

\section{Conflict of Interests}

The authors declare that there is no conflict of interests. 


\section{Authors' Contributions}

Concept/Design: EA, MAH. Data Collection and/or

Processing: EA, MAH. Data analysis and interpretation:

EA, MAH. Literature Search: EA, MAH. Drafting manuscript: EA, MAH. Critical revision of manuscript:

EA, MAH. Supervision: EA.

\section{REFERENCES}

1. Bilton D. Update on non-cystic fibrosis bronchiectasis. Curr Opin Pulm Med. 2008;14(6):595-599.

2. Zhang P, Jiang G, Ding J, Zhou X, Gao W. Surgical Treatment of Bronchiectasis: A Retrospective Analysis of 790 Patients. Ann Thorac Surg. 2010;90(1):246-251.

3. Özkan M, Sakallı MA, Yenigün BM, et al. Surgical Treatment in Bronchiectasis: Results of 191 Patients. J Ankara Univ Fac Med. 2019;72(2):241-246.

4. Balci AE, Balci TA, Eren S, Nazaroglu H, Eren MN. Bronşektazide operasyonun rolü: Cerrahi ve medikal tedavinin karşılaştırması. Turk Gogus Kalp Dama. 2002;10(2):95-101.

5. Giovannetti R, Alifano M, Stefani A, et al. Surgical treatment of bronchiectasis: early and long-term results. Interact Cardiovasc Thorac Surg. 2008;7(1):609-612.

6. Ibarrola M, Solís M, Buero A, et al. Surgical Treatment of Bronchiectasis: A Retrospective Long-Term Analysis of 55 Patients. EC Pulm Resp Med. 2020;9(1):01-08.

7. Kutlay H, Cangir AK, Enön S, et al. Surgical treatment in bronchiectasis: analysis of 166 patients. Eur J Cardiothorac Surg. 2002;21(4):634-637.

8. Deslauriers J, Goulet S, Francois B. Surgical treatment of bronchiectasis and broncholithiasis. In: Franco LF, Putnam JB, editors. Advanced Therapy in Thoracic Surgery. Hamilton, ON: Decker;1998:300-309.

9. Bagheri R, Haghi SZ, Fattahi MSH, Bahadorzadeh L. Surgical management of bronchiectasis: analysis of 277 patients. Thorac Cardiovasc Surg. 2010;58(5):291-294.
10. Hodder RV, Cameron R, Todd TRJ. Bacterial infections. In: Pearson FG, editor. Thoracic Surgery. New York: Churchill Livingstone; 1995.

11. Sirmali $M$, Karasu $\mathrm{S}$, Türüt $\mathrm{H}$, et al. Surgical management of bronchiectasis in childhood. EurJ Cardiothorac Surg. 2007;31(1):120-123.

12. Sunny SS, Davison J, De Soyza A. Management of noncystic fibrosis Bronchiectasis. Clin Pract. 2013;10(5):629-640.

13. Mathur M, Gupta S, Bhalla R, Mathur A. High Resolution Computed Tomography Assessment of Interstitial Lung Diseases and its Correlation with Spirometry Indices. J Clin Diag Res. 2017;11(11):7-12.

14. Gallucci M, di Palmo E, Berteli L, Camela F, Ricci G, Pession A. A pediatric disease to keep in mind: diagnostic tools and management of bronchiectasis in pediatric age. Ital J Pediatr. 2017;43(1):117.

15. Otgün I, Karnak I, Tanyel FC, Senocak ME, Büyükpamukçu N. Surgical treatment of bronchiectasis in children. J Pediatr Surg. 2004;39(10):1532-1536.

16. Yuncu G, Ceylan KC, Sevinc S, et al. Functional results of surgical treatment of bronchiectasis in a developing country. Arch Bronconeumol. 2006;42(4):183-188.

17. Doner E. Surgical Treatment of Bronchiectasis; Analysis of 2 Years. Osmangazi J Med. 2020;42(5):541-545.

18. Balkanli K, Genç O, Dakak M, et al. Surgical management of bronchiectasis: analysis and short-term results in 238 patients. Eur $\mathbf{J}$ Cardiothorac Surg. 2003;24(5):699-702.

19. Neves PC, Guerra M, Ponce P, Miranda J, Vouga L. Non-cystic fibrosis bronchiectasis. Interact Cardiovasc Thorac Surg. 2011;13(6):619-625.

20. Al-Refaie RE, Amer S, El-Shabrawy M. Surgical treatment of bronchiectasis: a retrospective observational study of 138 patients. J Thorac Dis. 2013;5(3):228-233.

21. Nadir A, Kaptanoğlu $M$, Gönlügür $U$, et al. Bronsektazinin cerrahi tedavisi: 36-olgunun değerlendirilmesi. T Klin J Med Sci. 2003:23(1):359365 .

22. Gursoy S, Ozturk AA, Ucvet A, Erbaycu AE. Surgical management of bronchiectasis: the indications and outcomes. Surg Today 2010;40(1):26-30.

23. Fan LC, Liang S, Lu HW, Fei K, Xu JF. Efficiency and safety of surgical intervention to patients with NonCystic Fibrosis bronchiectasis: a meta-analysis. Sci Rep. 2015;5(1):17382. 